\title{
Development and Performance Evaluation of Lime Harvesting Device
}

\author{
V. R. Vagadia ${ }^{1 *}$, H. H. Mashru², H. D. Rank ${ }^{2}$, G. V. Prajapati ${ }^{3}$, R. M. Satasiya ${ }^{2}$, R. Subbaiah ${ }^{4}$
}

${ }^{1}$ Dept. of Farm Engineering, College of Agriculture, Junagadh Agricultural University, Junagadh, Gujarat (362 001), India ${ }^{2}$ Soil and Water Engineering Department, ${ }^{2}$ Dept. of Renewable Energy Engineering, College of Agricultural Engineering and Technology, Junagadh Agricultural University, Junagadh, Gujarat (362 001), India

${ }^{3}$ Research, Testing and Training Centre, Junagadh Agricultural University, Junagadh, Gujarat (362 001), India

${ }^{4}$ College of Agricultural Engineering and Technology, Anand Agricultural University, Godhra, Gujarat (389 001), India

\section{Corresponding Author}

V. R. Vagadia

e-mail:vrvagadia@jau.in

\section{Article History}

Article ID: IJEP0362

Received in $04^{\text {th }}$ March, 2020

Received in revised form $17^{\text {th }}$ March, 2020

Accepted in final form 24 ${ }^{\text {th }}$ March, 2020

\begin{abstract}
Efforts were made to develop a hand tool for harvesting of lime fruits. Initially, survey was done to collect the data regarding traditional kagzilime fruit harvesting device adopted by the farmers. The problems faced with the traditional tool for lime fruit harvesting are alleviated in the JAU-Lime harvester by providing catching unit, fruit collecting mouth and conveyance pipe which reduces losses in terms of immature lime fall out and spoilage. It was compared with the traditional one in terms of number of fruits harvested per unit time, spoilage and immature fruit losses during harvesting. The average fruit harvesting capacity was recorded as $6.85 \mathrm{~kg} \mathrm{hr}^{-1}$ and $7.83 \mathrm{~kg} \mathrm{hr}^{-1} \mathrm{for} \mathrm{JAU-Lime}$ harvester and traditional harvester, respectively. The collected fruits were kept in same environment for 11 days to find the number of fruits spoiled. It was observed that up to $8^{\text {th }}$ day after harvesting, no spoilage was recorded in the lime harvested by JAU-Lime harvester. It was also recorded that after 11 days nearly $36.67 \%$ of limes were spoiled from the lots which were harvested by the traditional harvester. Average fruit spoilage was observed to be 15.45 and $2.12 \%$ in traditional harvester and JAU-Lime harvester, respectively. It was also observed that due to pulling effect, an average $3.84 \%$ immature fruits fall on the ground surface, while harvesting by traditional harvester compared to $1.37 \%$ in case of JAU-Lime harvester.
\end{abstract}

Keywords: Fruit harvester, fruit spoilage, lime harvester

\section{Introduction}

The growth of horticultural crops in India during the last two decades is increasing at an alarming rate. It covers about 12 million-ha area and contribute about $18.8 \%$ of the gross domestic product with $15.5 \%$ of the total agricultural export. India has emerged as the second largest producer of the fruits and vegetables after Brazil and China. Gujarat play a prominent role in horticultural production and produce about 2289.47 thousand metric tons of fruits (mango, sapota, kagzilime, banana, papaya, coconut, pomegranate and date palm) annually from an area of 176.70 thousand ha. The harvesting of fruits is done manually which is very labour intensive, time consuming and tedious. Mechanization in fruit crop cultivation is at very low level. The farmers generally use traditional hand tools for harvesting the fruits. Traditional tools result in high harvest losses due to low efficiency and energy intensive in operation. Unavailability coupled with high cost of human labour during the peak period adds another dimension to fruit growers.
In Gujarat, about 2,85,285 metric tons of lime is produced annually over an area of 27,931 hectares. Harvesting of lime fruits is one of the important operations carried out using manually operated inefficient traditional devices or by shaking the tree branches and then collecting the fruits from the ground surface. Thus, lime fruits get damaged when they fall on the ground surface. Also it is difficult to collect the fruits fallen on the ground surface because of narrow clearance between the branches and ground surface. If lemon fruits are directly collected from the tree by hand picking, then problem of pinching of plant thorns to the human body particularly to fingers and hands arises. Hence, keeping above facts in view the development of lime harvesting device was necessary.

\section{Materials and Methods}

\subsection{Design of lime harvester device}

The lime harvester devices were designed and developed at the Research, Testing and Training Centre (RTTC) and tested at Madhadibaugh farm, Department of Horticulture, JAU, Junagadh (Gujarat). 
Initially, survey was done to collect the data regarding traditional kagzilime fruit harvesting device adopted by the farmers (Plate 1). The age of the plantation at selected farm was 15 years. The information of kagzilime plant like, plant height, canopy radius and planting distance were collected and are shown in Table 1. In the traditional device, a simple half circular hook of GI wire is made and fitted to one end of the wooden handle. While harvesting the lime, the handle with hook is penetrated up to the location of the fruit in the canopy, brought inside the half circular of the hook, then the handle is pulled. The fruit falls by gravity on the ground surface within or outside the canopy. This traditional method causes damage to the fruit. Operator faces difficulty in collecting the fallen fruits from the ground due to narrow spacing between

\begin{tabular}{lccc}
\hline \multicolumn{4}{l}{ Table 1: Characteristics of kagzilime tree } \\
\hline Tree & $\begin{array}{c}\text { Height of } \\
\text { tree }(\mathrm{m})\end{array}$ & $\begin{array}{c}\text { Canopy ra- } \\
\text { dius }(\mathrm{m})\end{array}$ & $\begin{array}{c}\text { Planting distance, } \\
(\mathrm{R} \times \mathrm{P}) \mathrm{m}\end{array}$ \\
\hline 1 & 4.5 & 3.20 & $6 \times 6$ \\
2 & 4.3 & 3.10 & $6 \times 6$ \\
3 & 4.6 & 3.30 & $6 \times 6$ \\
4 & 4.5 & 3.25 & $6 \times 6$ \\
5 & 4.7 & 3.35 & $6 \times 6$ \\
6 & 4.4 & 3.15 & $6 \times 6$ \\
7 & 4.6 & 3.10 & $6 \times 6$ \\
8 & 4.2 & 3.35 & $6 \times 6$ \\
9 & 4.4 & 3.30 & $6 \times 6$ \\
10 & 4.5 & 3.25 & $6 \times 6$ \\
Average & 4.5 & 3.20 & $6 \times 6$ \\
\hline
\end{tabular}

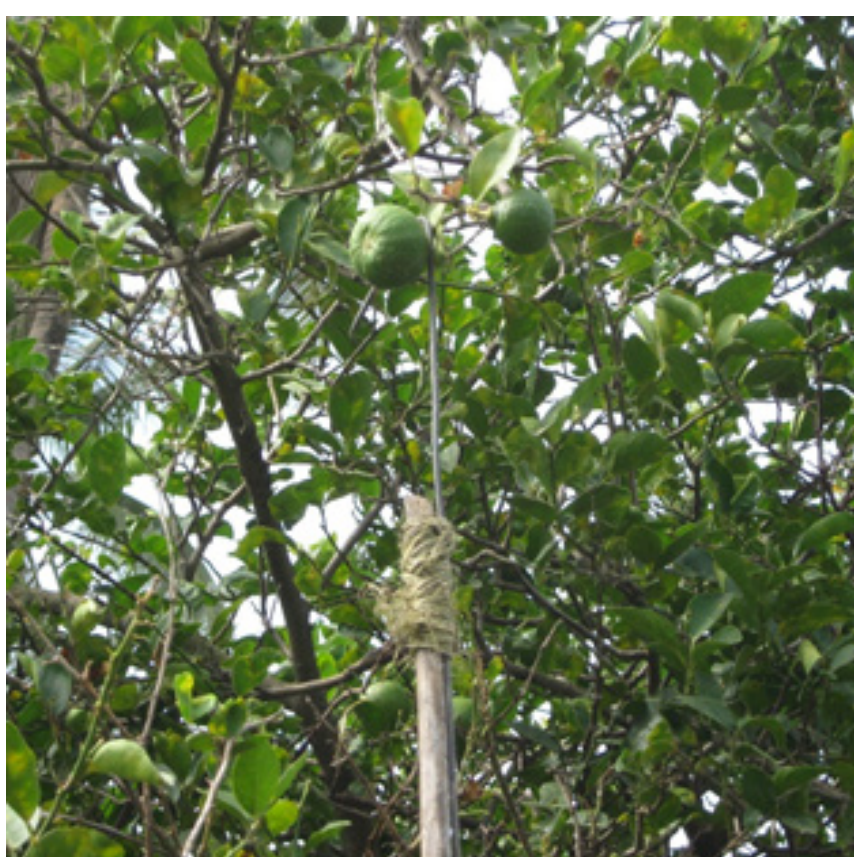

Plate 1: Traditional lime harvesting device the branches and ground surface. Pinching of plant thorns to the operator is the main problem when the fruits are being handpicked from inner side of the plant canopy. Hand picking is rather difficult and inefficient operation. After considering the collected information and problems faced for harvesting lime fruit, the manually operated device was developed (Plate 2) and tested. The required modifications were made consequently by stage I to IV as shown in Figure 1. Finally the reported device was developed and tested at field. The developed lime harvester contains fruit catching unit, fruit collection mouth, conveyance pipe and collection chamber.

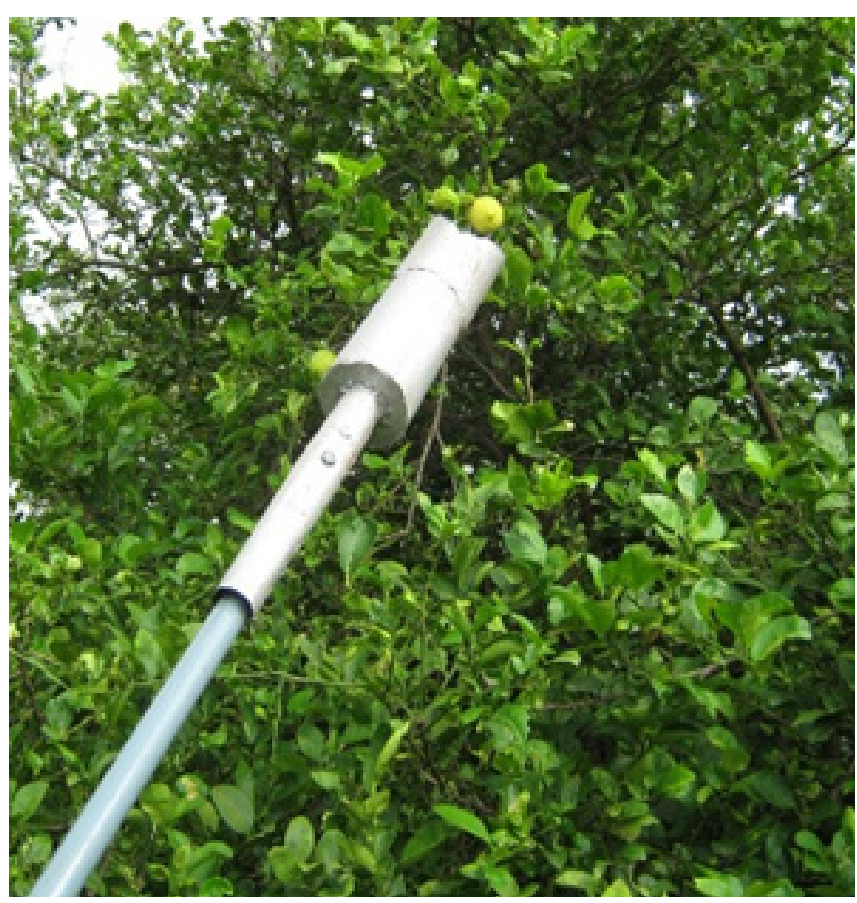

Plate 2: Initially developed lime harvesting device

\section{Results and Discussion}

After making required corrections at stage-I to stage-IV, finally the performance of the device developed at stage IV was found satisfactory. Five replications in terms of the changed trees were taken into account. The observations like number of fruits harvested, number of fruits missed and fall on the ground surface, number of immature fruit fall on the ground surface, time to unload the device, reset time and weight of fruit harvested were noted. The performance evaluation of the JAU-Lime harvester and traditional harvester are presented in Table 2-5.

The problems faced with the traditional tool for lime fruit harvesting are alleviated in the JAU-Lime harvester by providing catching unit, fruit collecting mouth and conveyance pipe which reduces losses in terms of immature lime fall out and spoilage. It was compared with the traditional one in terms of number of fruits harvested per unit time, spoilage and immature fruit losses during harvesting.

The average fruit harvesting capacity was recorded as 6.85 


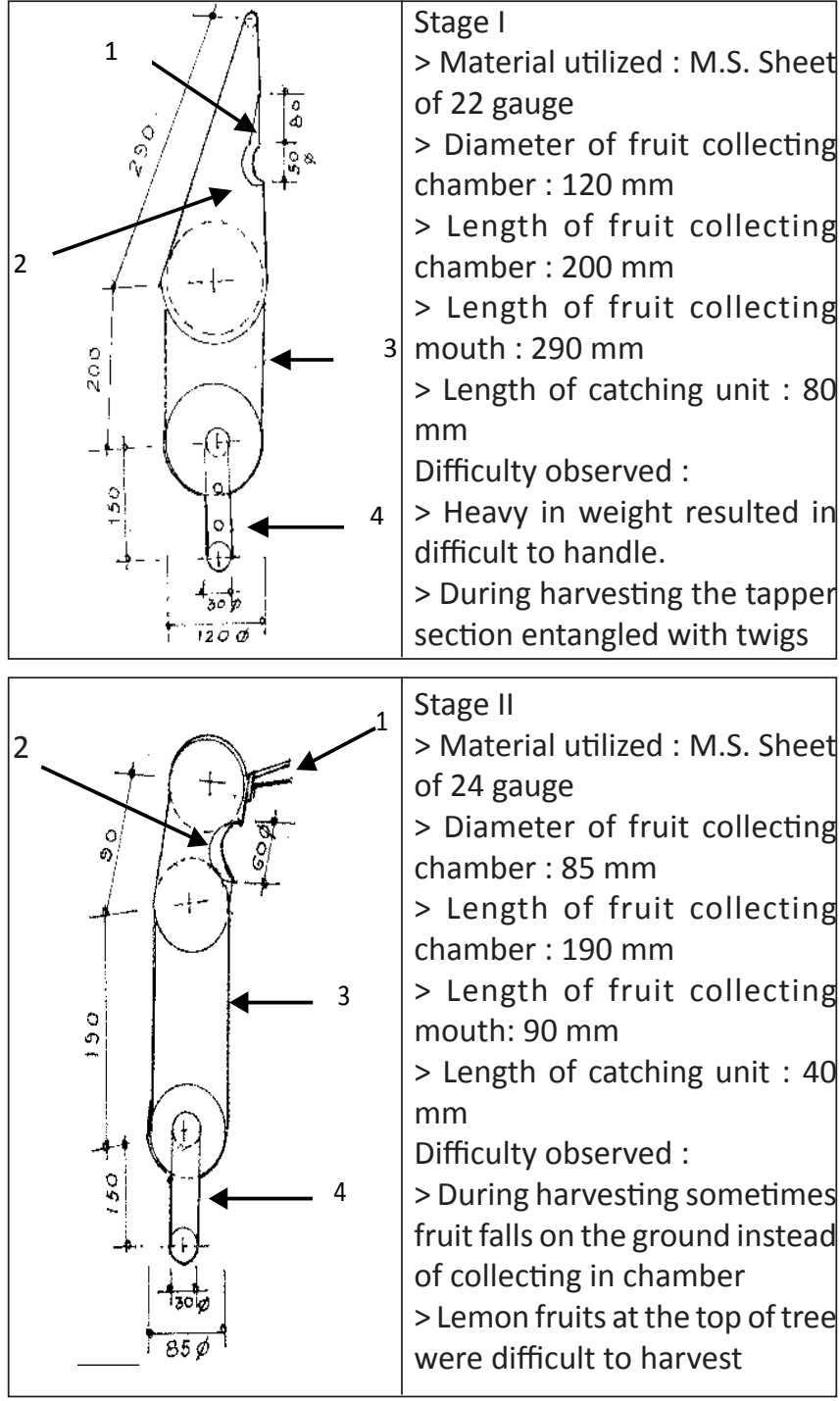

\begin{tabular}{|c|c|}
\hline $\begin{array}{l}\text { 1. Catching unit } \\
\text { 2. Fruit collecting mouth } \\
\text { 3. Fruit collecting chamber } \\
\text { 4. Handle } \\
\text { (All dimensions are in } \mathrm{mm} \text { ) }\end{array}$ & $\begin{array}{l}\text { Stage III } \\
>\text { Material utilized : M.S. Sheet } \\
\text { of } 24 \text { gauge } \\
>\text { Diameter of fruit collecting } \\
\text { chamber : } 85 \mathrm{~mm} \\
>\text { Length of fruit collecting } \\
\text { chamber : } 190 \mathrm{~mm} \\
>\text { Length fruit collecting mouth: } \\
90 \mathrm{~mm} \\
>\text { Length of catching unit : } 40 \\
\mathrm{~mm} \\
>\text { Height of feed throat : } 60 \mathrm{~mm} \\
\text { Difficulty observed: } \\
>\text { Visibility of fruit at top and } \\
\text { inside part of tree was difficult } \\
\text { due to half curved section. } \\
>\text { Half curved section also } \\
\text { damage twigs }\end{array}$ \\
\hline
\end{tabular}

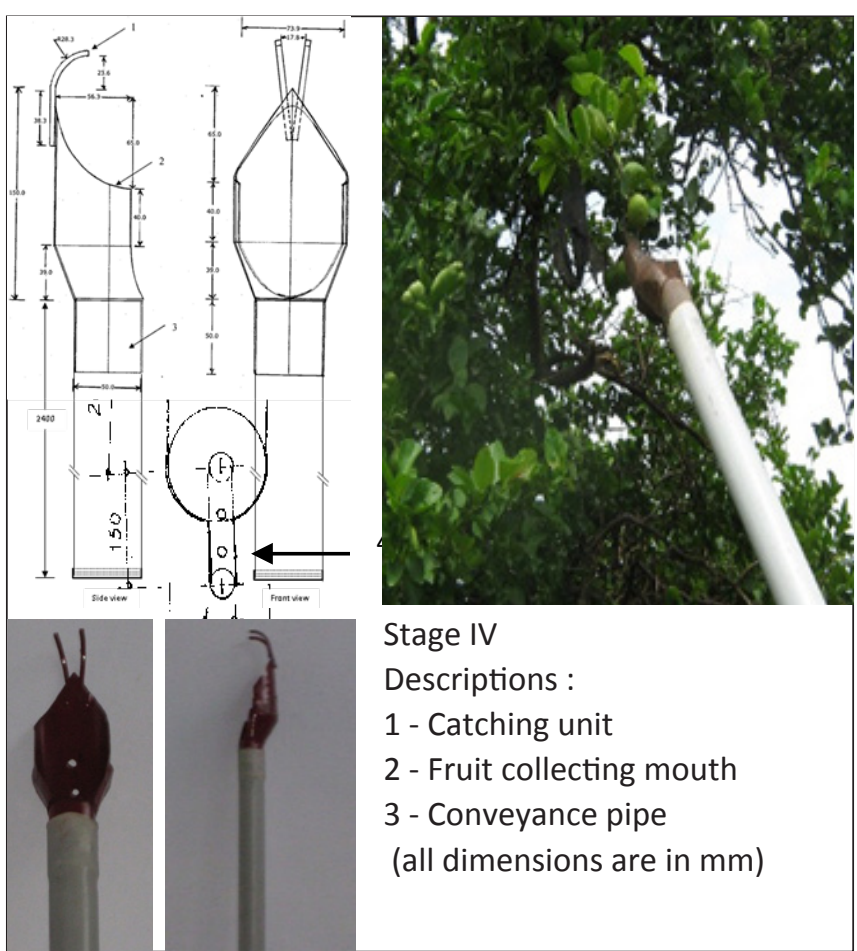

Figure 1 : Design drawing of JAU-Lime Harvester (Stage-I to IV)

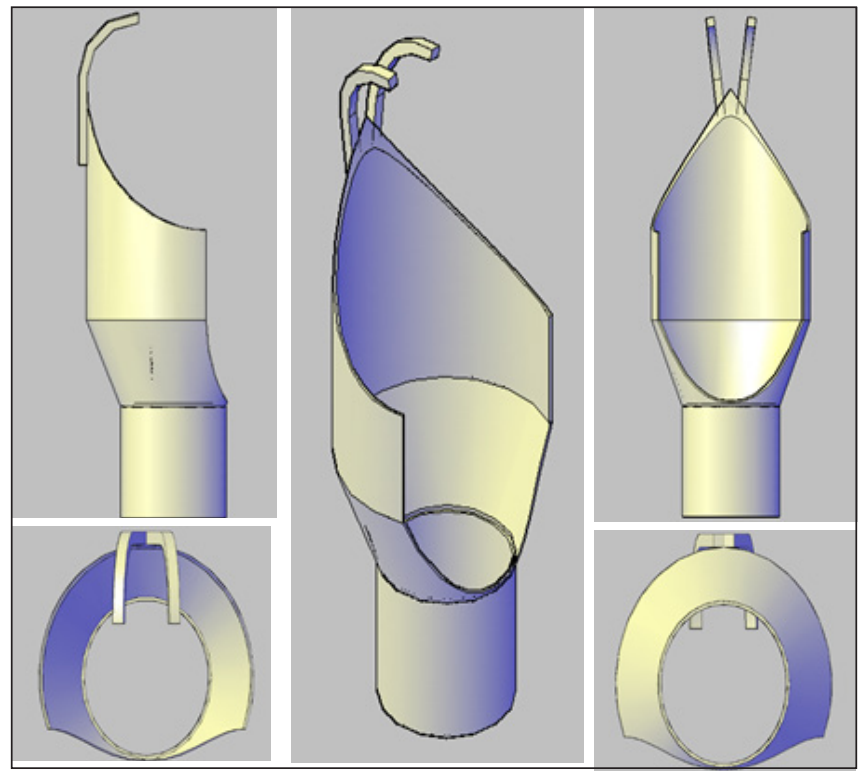

Figure 2: Sectional view of JAU-Lime Harvester

$\mathrm{kg} \mathrm{hr}^{-1}$ and $7.83 \mathrm{~kg} \mathrm{hr}^{-1}$ for JAU-Lime harvester and traditional harvester as shown in Table 6 . The collected fruits were kept in same environment for 11 days to find the number of fruits spoiled. It was observed that up to $8^{\text {th }}$ day after harvesting, no spoilage was recorded in the lime harvested by JAU-Lime harvester. It was also recorded that after 11 days, nearly $36.67 \%$ of limes were spoiled from the lots which were harvested by the traditional harvester. This is mainly due to the impact force given to the fruit at the time of harvesting (Table 7). On the eleventh day, $13.33 \%$ fruits were spoiled 
Table 2: Performance Evaluation of JAU-Lime Harvester (Set -1)

\begin{tabular}{|c|c|c|c|c|c|c|c|c|}
\hline \multirow[t]{2}{*}{ S. N } & \multirow[t]{2}{*}{$\begin{array}{l}\text { Replica- } \\
\text { tion }\end{array}$} & \multirow{2}{*}{$\begin{array}{l}\text { No. of fruits } \\
\text { collected in } \\
\text { the device dur- } \\
\text { ing harvesting }\end{array}$} & \multirow{2}{*}{$\begin{array}{l}\text { No. of fruits } \\
\text { missed \& fall } \\
\text { on the ground } \\
\text { surface }\end{array}$} & \multirow{2}{*}{$\begin{array}{c}\text { Total } \\
\text { fruits har- } \\
\text { vested }\end{array}$} & \multirow{2}{*}{$\begin{array}{l}\text { No. of im- } \\
\text { mature fruits } \\
\text { fallen on the } \\
\text { ground }\end{array}$} & \multirow{2}{*}{$\begin{array}{l}\text { Net time } \\
\text { taken } \\
\text { (min.) }\end{array}$} & \multicolumn{2}{|c|}{$\begin{array}{l}\text { Recurrence time }(\min ) \& \\
\text { events }\end{array}$} \\
\hline & & & & & & & $\begin{array}{l}\text { Unloading time } \\
\text { \& events }\end{array}$ & $\begin{array}{l}\text { Setting time } \\
\& \text { events }\end{array}$ \\
\hline$A$ & B & C & $D$ & $E=C+D$ & $F$ & G & $\mathrm{H}$ & I \\
\hline 1 & $\mathrm{R} 1$ & 204 & 60 & 264 & 5 & 60 & $2.4(10)$ & $1.2(10)$ \\
\hline 2 & $\mathrm{R} 2$ & 216 & 36 & 252 & 4 & 60 & $2.0(10)$ & $1.6(10)$ \\
\hline 3 & R3 & 240 & 48 & 288 & 5 & 60 & $1.8(10)$ & $1.8(10)$ \\
\hline 4 & $\mathrm{R} 4$ & 216 & 24 & 240 & 6 & 60 & $2.4(10)$ & $1.4(10)$ \\
\hline 5 & R5 & 228 & 36 & 264 & 2 & 60 & $2.6(10)$ & $2.0(10)$ \\
\hline
\end{tabular}

Table 2: Continue..

\begin{tabular}{|c|c|c|c|c|}
\hline $\begin{array}{l}\text { S I. } \\
\text { No. }\end{array}$ & $\begin{array}{l}\text { Time to collect missed fruits } \\
\text { ( }(\mathrm{min})\end{array}$ & Total time taken (min) & $\begin{array}{l}\text { Weight of fruits } \\
(\mathrm{kg})\end{array}$ & $\begin{array}{c}\text { Harvesting } \\
\text { Capacity }\left(\mathrm{kg} \mathrm{hr}^{-1}\right)\end{array}$ \\
\hline$A$ & J & $\mathrm{K}=\mathrm{G}+\mathrm{H}+\mathrm{I}+\mathrm{J}$ & $\mathrm{L}$ & $M$ \\
\hline 1 & 2.4 & 66.0 & 7.128 & 6.48 \\
\hline 2 & 2.0 & 65.6 & 7.308 & 6.68 \\
\hline 3 & 2.6 & 66.2 & 8.928 & 8.09 \\
\hline 4 & 2.2 & 66.0 & 7.200 & 6.55 \\
\hline 5 & 2.4 & 67.0 & 7.656 & 6.86 \\
\hline
\end{tabular}

\begin{tabular}{|c|c|c|c|c|c|c|c|c|}
\hline $\begin{array}{l}\text { Sr. } \\
\text { No }\end{array}$ & $\begin{array}{l}\text { Repli- } \\
\text { cation }\end{array}$ & $\begin{array}{l}\text { No. of } \\
\text { fruits har- } \\
\text { vested }\end{array}$ & $\begin{array}{l}\text { No. of imma- } \\
\text { ture fruits fallen } \\
\text { on the ground }\end{array}$ & $\begin{array}{l}\text { Net time taken } \\
\text { for harvesting } \\
\text { (min) }\end{array}$ & $\begin{array}{l}\text { Time required } \\
\text { for collection } \\
\text { (min) }\end{array}$ & $\begin{array}{l}\text { Total time } \\
\text { taken (min) }\end{array}$ & $\begin{array}{l}\text { Weight of } \\
\text { collected } \\
\text { fruits }(\mathrm{kg})\end{array}$ & $\begin{array}{l}\text { Capacity } \\
\left(\mathrm{kg} \mathrm{hr}^{-1}\right)\end{array}$ \\
\hline$A$ & B & C & $\mathrm{D}$ & $E$ & $\mathrm{~F}$ & $\mathrm{G}=\mathrm{E}+\mathrm{F}$ & $\mathrm{H}$ & I \\
\hline 1 & R1 & 420 & 16 & 60 & 30 & 90 & 12.600 & 8.40 \\
\hline 2 & $\mathrm{R} 2$ & 384 & 18 & 60 & 24 & 84 & 11.904 & 8.50 \\
\hline 3 & R3 & 432 & 10 & 60 & 42 & 102 & 12.096 & 7.12 \\
\hline 4 & R4 & 408 & 14 & 60 & 36 & 96 & 11.832 & 7.40 \\
\hline 5 & R5 & 360 & 17 & 60 & 27 & 87 & 10.440 & 7.20 \\
\hline
\end{tabular}

Table 4: Performance evaluation of JAU-Lime Harvester (Set-2)

\begin{tabular}{|c|c|c|c|c|c|c|c|c|}
\hline \multirow[t]{2}{*}{ S. N } & \multirow[t]{2}{*}{$\begin{array}{l}\text { Replica- } \\
\text { tion }\end{array}$} & \multirow{2}{*}{$\begin{array}{l}\text { No. of fruits } \\
\text { collected in } \\
\text { the device dur- } \\
\text { ing harvesting }\end{array}$} & \multirow{2}{*}{$\begin{array}{l}\text { No. of fruits } \\
\text { missed \& fall } \\
\text { on the ground } \\
\text { surface }\end{array}$} & \multirow{2}{*}{$\begin{array}{l}\text { Total } \\
\text { fruits har- } \\
\text { vested }\end{array}$} & \multirow{2}{*}{$\begin{array}{l}\text { No. of im- } \\
\text { mature fruits } \\
\text { fallen on the } \\
\text { ground }\end{array}$} & \multirow{2}{*}{$\begin{array}{l}\text { Net time } \\
\text { taken } \\
\text { (min.) }\end{array}$} & \multicolumn{2}{|c|}{$\begin{array}{l}\text { Recurrence time (min) \& } \\
\text { events }\end{array}$} \\
\hline & & & & & & & $\begin{array}{l}\text { Unload- } \\
\text { ing time \& } \\
\text { events }\end{array}$ & $\begin{array}{l}\text { Setting time } \\
\& \text { events }\end{array}$ \\
\hline$A$ & B & C & $D$ & $E=C+D$ & $\mathrm{~F}$ & G & $\mathrm{H}$ & I \\
\hline 1 & $\mathrm{R} 1$ & 156 & 48 & 204 & 3 & 60 & $1.6(10)$ & $1.6(10)$ \\
\hline 2 & $\mathrm{R} 2$ & 228 & 60 & 288 & 2 & 60 & $2.4(10)$ & $1.0(10)$ \\
\hline 3 & R3 & 180 & 72 & 252 & 4 & 60 & $2.2(10)$ & $1.4(10)$ \\
\hline 4 & $\mathrm{R} 4$ & 240 & 60 & 300 & 3 & 60 & $1.8(10)$ & $1.2(10)$ \\
\hline 5 & R5 & 204 & 36 & 240 & 5 & 60 & $2.6(10)$ & $2.0(10)$ \\
\hline
\end{tabular}




\begin{tabular}{|c|c|c|c|c|}
\hline SI. No. & $\begin{array}{l}\text { Time to collect missed } \\
\text { fruits (min) }\end{array}$ & Total time taken (min) & Weight of fruits (kg) & $\begin{array}{c}\text { Harvesting } \\
\text { Capacity }\left(\mathrm{kg} \mathrm{hr}^{-1}\right)\end{array}$ \\
\hline A & J & $\mathrm{K}=\mathrm{G}+\mathrm{H}+\mathrm{I}+\mathrm{J}$ & L & M \\
\hline 1 & 2.4 & 65.6 & 5.508 & 5.04 \\
\hline 2 & 2.8 & 66.2 & 8.352 & 7.57 \\
\hline 3 & 2.6 & 66.2 & 7.308 & 6.62 \\
\hline 4 & 1.8 & 64.8 & 9.000 & 8.33 \\
\hline 5 & 1.6 & 66.2 & 6.960 & 6.31 \\
\hline
\end{tabular}

Table 5: Performance evaluation of traditional harvester (Set-2)

Sr. Repli- No. of fruits No. of immature fruits Net time Time for col- Total time Weight of col- Capacity No. cation harvested fallen on the ground taken (min.) lection (min.) taken (min.) lected fruits $(\mathrm{kg}) \quad\left(\mathrm{kg} \mathrm{hr}^{-1}\right)$

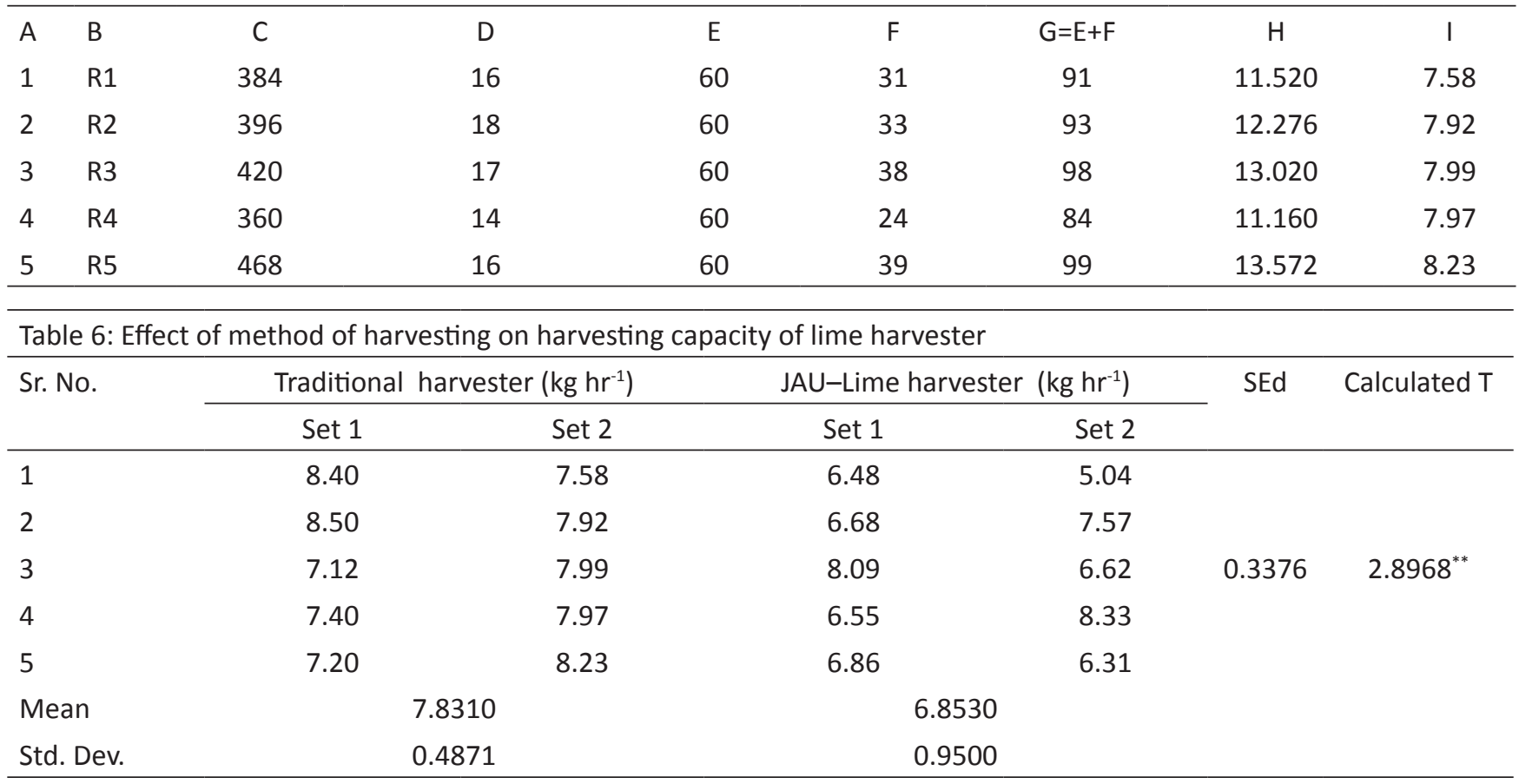

$* \rightarrow$ Significant at $5 \%$ level of Significant; ${ }^{* *} \rightarrow$ Significant at $1 \%$ level of significant

\begin{tabular}{|c|c|c|c|c|c|c|}
\hline \multirow[t]{2}{*}{ Sr. No. } & \multicolumn{2}{|c|}{$\begin{array}{l}\text { Traditional harvester } \\
\qquad\left(\mathrm{kg} \mathrm{hr}^{-1}\right)\end{array}$} & \multicolumn{2}{|c|}{$\begin{array}{l}\text { JAU-Lime harvester } \\
\left(\mathrm{kg} \mathrm{hr}^{-1}\right)\end{array}$} & \multirow[t]{2}{*}{ SEd } & \multirow[t]{2}{*}{ Calculated T } \\
\hline & Set 1 & Set 2 & Set 1 & Set 2 & & \\
\hline 1 & 3.74 & 3.94 & 1.53 & 1.2 & 0.1929 & $12.8280^{* *}$ \\
\hline Mean & \multicolumn{2}{|c|}{3.8400} & \multicolumn{2}{|c|}{1.3650} & & \\
\hline Std. Dev. & \multicolumn{2}{|c|}{0.1414} & \multicolumn{2}{|c|}{0.2333} & & \\
\hline
\end{tabular}

$* \rightarrow$ Significant at $5 \%$ level of Significant; ${ }^{* *} \rightarrow$ Significant at $1 \%$ level of significant

from lots which were harvested by JAU-Lime harvester. Average fruit spoilage was observed to be 15.45 and $2.12 \%$ in traditional harvester and JAU-Lime harvester, respectively. Harvesting of kinnow fruit from traditional method leads to damage of $8.80 \%$ (Chaudhary et al., 2019). Similar type of work has also been done by Wade (2010) and Sabale et al. (2016) in guava and oranges. It was also observed that due to pulling effect, an average $3.84 \%$ immature fruits fall on the ground surface while harvesting by traditional harvester compared to $1.37 \%$ in case of JAU-Lime harvester as shown in Table 8. 


\begin{tabular}{|c|c|c|c|c|c|c|}
\hline \multirow[t]{2}{*}{ Sr. No. } & \multicolumn{2}{|c|}{ Traditional harvester $\left(\mathrm{kg} \mathrm{hr}^{-1}\right)$} & \multicolumn{2}{|c|}{ JAU-Lime harvester $\left(\mathrm{kg} \mathrm{hr}^{-1}\right)$} & \multirow{2}{*}{ SEd } & \multirow{2}{*}{ Calculated T } \\
\hline & Set 1 & Set 2 & Set 1 & Set 2 & & \\
\hline 1. & 0 & 0 & 0 & 0 & & \\
\hline 2. & 06.67 & 06.67 & 0.00 & 0.00 & & \\
\hline 3. & 06.67 & 06.67 & 0.00 & 0.00 & & \\
\hline 4. & 13.33 & 06.67 & 0.00 & 0.00 & & \\
\hline 5. & 13.33 & 13.33 & 0.00 & 0.00 & & \\
\hline 6. & 13.33 & 13.33 & 0.00 & 0.00 & 2.511 & $5.3098^{* *}$ \\
\hline 7. & 13.33 & 13.33 & 0.00 & 0.00 & & \\
\hline 8. & 13.33 & 13.33 & 0.00 & 0.00 & & \\
\hline 9. & 26.67 & 26.67 & 0.00 & 6.67 & & \\
\hline 10. & 26.67 & 33.33 & 6.67 & 6.67 & & \\
\hline 11. & 33.33 & 40.00 & 13.33 & 13.33 & & \\
\hline Mean & \multicolumn{2}{|c|}{15.4541} & \multicolumn{2}{|c|}{2.1214} & & \\
\hline Std. Dev. & \multicolumn{2}{|c|}{10.9611} & \multicolumn{2}{|c|}{4.3086} & & \\
\hline
\end{tabular}

$* \rightarrow$ Significant at $5 \%$ level of Significant; ${ }^{* *} \rightarrow$ Significant at $1 \%$ level of significant

\section{Conclusion}

Result revealed that JAU-Lime harvester reduced the per cent of immature fruit fall on the ground surface and spoilage of the lime. Therefore, the farmers having kagzilime orchards are advised to use the JAU-Lime harvester to reduce losses like spoilage and immature lime fall-up.

\section{References}

Chaudhary, D., Mehta, A.K., Kamendra, 2019. Development and performance evaluation of manual harvesting device for kinnow (Citrus nobilis $\times$ Citrus deliciosa) fruit. International Journal of Chemical Studies 7, 4796-4802.

Sabale, P.R., Nalawade, R.D., Bhosale, T.B., Meena, S.S., 2016. Development of manual orange (Citrus sinensis) fruit harvesting system. International Journal of Current Microbiology and Applied Sciences 6, 3427-3433.

Wade, H.V., 2010. Development of ergo-friendly harvesting system for guava (Psidium guajava) fruit. Ph.D. thesis. Maharana Pratap University of Agriculture and Technology, Udaipur, Rajasthan. 